\title{
Microenterprises Targeting Youth Group to Socioeconomic Development: The Case of Addis Ababa, Ethiopia
}

\author{
Markos Kidane ${ }^{1}$, Dugassa Mulugeta ${ }^{2}$, Addis Adera $^{3,}$,, Yonas Yimmam ${ }^{3}$, Tigabu Molla ${ }^{4}$ \\ ${ }^{1}$ Department of Economics, Faculty of Business and Economics, Unity University, Addis Ababa, Ethiopia \\ ${ }^{2}$ Department of Economics, Faculty of Business and Economics, Addis Ababa Science University, Addis Ababa, Ethiopia \\ ${ }^{3}$ Department of Nursing, Faculty of Health Sciences, Woldia University, North Wollo, Amhara Region, Woldia, Ethiopia \\ ${ }^{4}$ Department of Economics, Faculty of Business and Economics, Woldia University, North Wollo, Amhara Region, Woldia, Ethiopia
}

\section{Email address:}

markos.kidane@yahoo.com (M. Kidane), addisaderagebru@gmail.com (A. Adera), yonasyimam@gmail.com (Y. Yimmam), jenetoforum@yahoo.com (T. Molla)

\section{To cite this article:}

Markos Kidane, Dugassa Mulugeta, Addis Adera, Yonas Yimmam, Tigabu Molla. Microenterprises Targeting Youth Group to Socioeconomic Development: The Case of Addis Ababa, Ethiopia. International Journal of Business and Economics Research.

Vol. 4, No. 3, 2015, pp. 144-156. doi: 10.11648/j.ijber.20150403.17

\begin{abstract}
Back ground: The sources of unemployment has been identified as one of the major challenges facing young people around the world, with the ranging from $25 \%$ to $45 \%$ in most developing countries, "self-employment" and microenterprise as the only way to reach the poorest of the poor". The unemployment rate of youth group is estimated to $26.1 \%$ based on CSA urban employment unemployment survey report 2010. Objective: The main objective of this study was to assess, and analyze microenterprises targeting youth to socioeconomic development in terms of poverty reduction, women empowerment, employment, and entrepreneurship. Method: The study was used a survey method. The survey method involved 120 micro enterprises which operated by youth groups. The sampling method was involved in ten sub-cities of Addis Ababa. The majority micro and small enterprise activity identification was based on the available information from MSE package and selected randomly. Data analysis was made by using descriptive statistics. Results: The results of this survey study, shows that majority of micro enterprises were, in the form of corporation, obtained their sources of initial capital from microfinance institutions, formed between years (2005 to 2008), set their vision to their enterprises during operation, profit earning microenterprises, survival microenterprises have a strategic plan of diversification, and have only permanent employees. Moreover, 1052 number of employees were working in different activities, however, from part time youth employees majority of them were family members. Additionally, majority of microenterprises were demanding growth oriented supports, were provided financial and non-financial supports from Addis Ababa MSE Agency and demanding in the future, were benefited from the different supports of governmental organizations, however, the remaining enterprises were leveled as very important to its essentiality. Furthermore, most of the respondents believed that employment in microenterprises could reduce poverty, and leveled as high in terms of its extent of importance to poverty reduction. From the available psychosocial constraints afraid of failure and criticism, faulty socialization, and low dignity of labor and inadequate motivation are the most serious problems that young entrepreneurs are facing. Conclusion: Institutions have to create favorable environments for youth targeting microenterprises such as fast credit access, systematic and easy collateral, and terms of payment. Additionally, researchers and policy makers have to emphasize for the sector growth and development specifically to youth target microenterprises, which in turn results to provide favorable policy framework.
\end{abstract}

Keywords: Microenterprises, Targeting Youth Group, Socioeconomic, Development

\section{Introduction}

The process of socio economic change is an intrinsic part of human civilization. Man has been striving carelessly to discover the secrets of nature and there by benefit immensely, in creating a peaceful, rich life for himself and his fellow-beings. Man has benefited by agricultural, industrial and information activities. New business 
formation is the result of harassing human skills with the developed technology, added by available capital as well as other infrastructure to set in a development process (Vasant, 2001).

"The main development agenda of the Ethiopian government is poverty reduction. All the country's development policies and strategies are therefore, geared towards this end. On the basis of the experiences gained so far, and the national vision, the Growth and Transformation Plan (GTP) has been prepared with clear objectives and targets through wide public participation at both the federal and regional levels. Implementation of the GTP requires huge resources and commitments. To this effect, emphasis given to ensuring effective public participation in implementation and monitoring of the plan, efficient and effective utilization of all available capacities of the public, the government and the private sector as well as better coordination and cooperation with the private sector and development partners. In this connection, special emphasis is given to encourage citizens to increase their savings and to strengthen the overall level of domestic savings for productive investment in GTP's priority programs ... it is only when every citizen makes a concerted effort with commitment, and sense of urgency to discharge his/her own responsibility that the effective implementation of GTP can be realized. This requires a fundamental change of thinking on the part of actors and stake holders, particularly citizens, professionals, investors and the leadership, with respect to the implementation of the key directions envisaged in the GTP”. Sufian Ahmed, Minster, MOFED (MOFED 2010 G.C;Murati and Weda.,2012).The benefit of micro enterprises in terms of poverty alleviation and reducing unemployment together with the Ethiopian government growth and transformation plan strategic pillars, the participation of youth and women is critical. In Ethiopia, based on the national strategy, regional governments have developed their own regional Micro and Small Enterprises development strategies. (Gerehiwot and Wolday 2001 G.C;Das and Bhowal.,2013).

The on-going micro and small enterprise development complemented by the formulation and implementation of women and youth packages is to address the unemployment and under employment problems. Given these on-going efforts, the challenges may not be in surmount able. (MOFED 2010 G.C).In Ethiopia, especially in urban areas, strengthening, expanding, and development of MSEs could serve as the major instrument in order to alter unemployment and poverty problems. In respect to this, in different activities, many people were beneficial from the job opportunities of which MSE performed activities. In past five years, six growth-oriented sectors were identified which were expected to create many job opportunities. As a result, many people became beneficiary. In general, the job opportunity will be created for TVET-graduate youth groups, women (housewives'), and other dwellers of the city through MSEs (MSE 1998 G.C).It believed that, the major source of social problem to youth group is lowest economic capacity (AAYA 2011G.C).Right from industrial revolution and even further, we can see the efforts put in to improve existing practices. Typically, the classical industrial engineering principle says; there is always a better method than the existing. Here the "better" ultimately means improved efficiencies, effectiveness and economics. If we understand the motto of this principle deeply, we may find the basic motivation of the Keizen in it. In fact, this principle clearly supports the view that nothing is best for forever (Altekar, 2007 G.C).It is clear that micro enterprises targeting youth groups reduce unemployment problem and alleviate poverty sustainability while these micro enterprises grow ( a priori as incubation to small enterprises) given that citrus paribus. To this respect, this study intends to asses and analyze the status, shortcomings/constrains, and prospects of micro enterprises target youth group (both male and female between ages 15-29) in Addis Ababa. This study has been organized in to four chapters. The first chapter deals with the problem and its approach such as objective of the study, research methodology, scope of the study, significance of the study, definition of used terms, and limitation of the study. The researcher of this study. The fourth chapter is an end to this study, which consists of summary of findings, conclusion and recommendation. Lastly, necessary documents attached at the end of this study such as references and annexes. An enterprise is group of people with a common goal, having resources (money, manpower, materials, machines, technologies etc) to achieve that goal. (Altekar, 2007 G.C; Prezioso and Coronato., 2014).

Operational Definitions

The term "micro-enterprise" connotes different entities and sectors depending on the country. Generally speaking, in developing countries comprises the vast majority of the small business sector are results of the relative lack of formal sector jobs available for the poor. These micro entrepreneurs operate micro enterprises not by choice, but out of necessity, where as in developed countries, micro enterprises comprise the smallest end (by size) of the small business sector.

Micro enterprise development: - refers to the package of services, policies, programs, and institutions intended to develop micro enterprises.

Micro finance: - refers to the package of micro financial services including lending and saving.

Micro finance institutions:-refers to institutions that provide micro finance services. These may include nongovernmental institutions, credit cooperatives, credit unions and banks.

Non-financial services-refers to the collection of programs and services that deliver inputs other than finance. They are sometimes referred to as business development services. Examples are technical skills, training, business training, marketing information and assistance, design and other forms of product development, technology transfer, assistance in the procurement of raw materials, the development of organizations of micro entrepreneurs, and 
so on.

Social intermediation: - describes training and other support that may be provide to prospective poor borrowers to help them acquire skills and values which they need to initiate micro enterprises. Social intermediation services include training in credit norms and procedures, saving discipline, and assistance in organizing in to groups. Because it is the other coin of credit delivery, it is not generally regarded as a non-financial service.

\section{Methods and Materials}

\subsection{Method of Data Collection}

In order to gather the necessary data and information, the researcher undertakes the following methods:

\subsubsection{Interview}

The study undertake interview to the concerned governmental, non-governmental, social, financial organizations in order to gather the necessary data. The selection of these organization held on the basis of information available in Addis Ababa micro and small enterprise agency in which, participating in terms of micro and small enterprises promotion in different aspects. Interview method undertakes the use of organized interview guide, which attached at the end of this study under the annex part. This method enabled the researcher of this study, to have a further look on the heterogeneous microenterprises, and to their overall understanding through implementing it in the study sample focus group. This in turn resulted to obtain sufficient inputs to data analysis.

\subsubsection{Questionnaires}

This study have undertaken by accompanying structured and unstructured questionnaires, which believed as essential for investigating the necessary information, and in turn enabled this researcher to achieve its general and specific objectives.

\subsubsection{Direct Observation}

This study undertook direct observation for the sake of further understanding to micro enterprises undertaken by youth groups in Addis Ababa. The available data on micro enterprises specifically to youth group is limited, scattered and not organized. This study collected pieces of information from various sources, in order to analyze the status, shortcomings, and prospects of micro enterprise target youth group in Addis Ababa.

\subsection{Method of Analysis}

This study used descriptive analysis. The data analysis were made by using descriptive to describe the characteristics of the sample and to make judgments about the characteristics of whole population i.e. Addis Ababa. The analysis was based on the available essential documents, published or unpublished (i.e. on basis of primary and secondary data). Additionally, the study was used statistical measures, flow diagrams, flow charts, tables, graphs, and pie charts for effective data analysis and presentation purpose. Moreover, Microsoft Excel 2007 and Microsoft Word 2007 were used for effective analysis purpose.

Statistical measures such as measures of arithmetic mean, and count were used as per the need during data analysis and presentation. In addition, other techniques such as frequency and percentile were implemented in it.

\subsection{The Study Area and Period}

Addis Ababa is the highest city in terms of size, microenterprise concentration, and urban population in Ethiopia. The unemployment rate is expected $31.46 \%$ according to CSA Statistical Report on the 2010 Urban Employment Unemployment Survey. In Addis Ababa, Micro and Small Enterprise Program started before 7 years (1996 to 2004). This program targeted different parties of the society. (MSE 2010)Despite, this study covers micro enterprises targeting youth group in Addis Ababa.

\subsection{Description of the Study Design}

This study was used both qualitative and quantitative approaches. The quantitative approach used survey method in order to form a database from which to infer relationships of population. This study practiced a survey method by using sampling techniques such as stratified, random and, purposive sampling techniques.

\subsection{Research Design}

Generally, under economic, social, and business researches: importance is given to historical, case study, and survey research methods. Each of the above methods has their own advantages and disadvantages. However, the researcher has to have a priori knowledge to their advantages and disadvantages of each methods stated before. However, understanding of the research area subject matter is critical in selection of a research method. The researcher of this study tried to understand the various aspects of micro-enterprises through gathering different information to the various aspects of micro enterprises and youth groups specifically in Addis Ababa. Thus, by accompanying the above stated factors and other advantages of the specified method together with the presence of the available information to micro enterprises targeting youth group in the case of Addis Ababa, the researcher of this study intended to select a survey method. However, the selection of this method dictated by taking in to consideration factors such as techniques of investigation. Hence, survey method is the technique of gathering data from population by applying personal contact, and interview when adequate information about a certain problem is not available in records, files and other sources. To this end, the availability of data to micro enterprises targeting youth group in Addis Ababa is very limited. Thus, the limitation of organized data, specifically to the aspects 
of this study, the researcher of this study intended to use a survey method. Despite, a survey research is an organized attempt to analyze, interpret, and report the present status of social institution group area, thus, the researcher of this study believed it as the better method to undertake this study effectively and to look beyond. The researcher used interview, questionnaire and direct observation techniques for the sake of data collection.

\subsection{Sampling Method}

Firstly, the sampling method was involved in ten subcities of Addis Ababa. The sampling distribution across sub cities of Addis Ababa dictated by, the available financial and time resources. Secondly, the major micro and small enterprise activity identification was based on the available information from MSE packages prepared by Addis Ababa MSE Agency and selected randomly. Then, the sample of 120 micro enterprises were selected and distributed across all sub cities randomly.

\subsection{Types of Data}

This study used both primary and secondary data, which is vital for the accomplishment of this study as it should be. Secondary data included small- scale industry survey of years (2002-2008 G.C) undertaken by Ethiopian Statistics Agency and data on microenterprises gathered by Addis Ababa Micro and Small Enterprises Agency. It also included reports of Addis Ababa youth association and other stakeholders which are involving in small and micro enterprise development.

Primary data collection was in terms of both quantitative and qualitative forms. This researcher believes that the inclusion of primary data enabled this study to accompany the necessary information in realities of Addis Ababa, specifically, micro enterprises targeting youth group, which in turn results to look this study, as it should be.

\subsection{Sampling Procedure and Data Collection}

This study used a survey method in order to gather the primary data from youth group microenterprises in Addis Ababa. In order to gather the necessary data, the researcher also used interview, observation, and both organized and non-organized questionnaires.

The interview method were under taken by interviewing workers of Addis Ababa City Administration Micro and Small Enterprises Agency, Addis Ababa Youth Association, CSA, Addis Ababa Credit and Saving institutions, and some micro enterprise operators who belongs to youth category. Additionally, an interview were held by using interview guide which is attached in the annex part of this study see annex number 1 .

Observation method were done by observing Cobble
Stone projects, Micro and small enterprises promotional exhibition in Arada and Gullele sub-cities, and other micro enterprise activities such as urban agriculture, food processing and construction activities specifically undertaking by youths. This study also used questionnaire method, which has been performed in two stages. First, the questionnaires were prepared in English language for the sake of fulfilling academic medium of instruction. Then, the questioners interpreted in to Amharic language for the sake of simplification (easiness) for respondents. Since, the respondents academic background differs, the researcher believed that being the questionnaires interpreted in to Amharic language, respondent of youth micro enterprise operators can respond easily which in turn enables to gather the necessary data and information. Although, the questioners were prepared, by using organized and nonorganized questionnaire methods. After the questionnaire interpreted and prepared by Amharic language, distributed to ten selected sub cities randomly. Then, while the questionnaires were distributed, it was done by finding "Kebele" offices in each sub cities and thus through asking information " Kebele" workers to the location of youth target micro enterprises. After the location of youth group micro enterprises identified, the questionnaires were provided to youth micro enterprise operators-owners, then, the questionnaires were collected after they were filled by youth micro enterprise operators (respondents of questionnaires) ,immediately, the questionnaires were checked for errors and were returned back for respondents to correct errors. After the above-mentioned steps, the questionnaires became ready to data encoding stage. After the results of the questionnaires were collected and became ready for data encoding stage, the collected questionnaires were coded from one to one hundred twenty. This task was made for the easiness of correcting data encoding errors. After that, the coded questionnaires also coded, in a manner to be easy for SPSS data encoding purpose (i.e. each questions and choices). Then, the collected data encoded to SPSS version 13.0. The data encoding activity were made in two steps. First, the coded questions and their respective choices were encoded under variable view category of SPSS version 13.0 software, furthermore, name of variable, data type, label, and values of each question were encoded. Second, the values of each coded question and their respective choice were encoded to the data view category of SPSS version 13.0 software. Next, the encoded data checked for data encoding errors .Afterwards, the encoded data became cleaned and ready for analysis purpose.

\subsection{The Model}

\subsubsection{Youth Groups'Microenterprises Model (YGMEsM)}




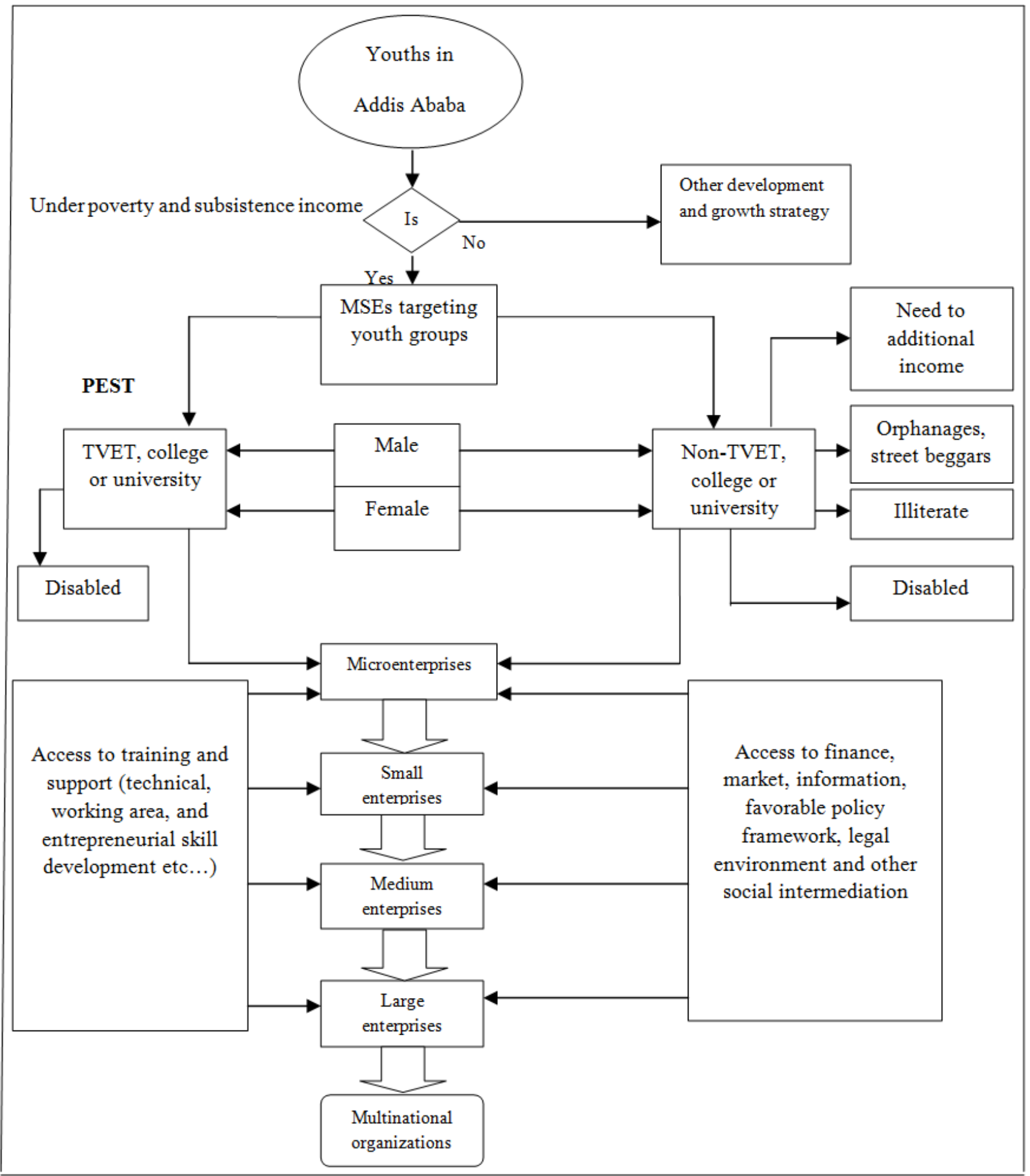

Fig. 1. Youth Groups' Microenterprises Model (YGMEsM) 5

Key:-PEST: $\mathrm{P}=$ Political legal environment, $\mathrm{E}=$ Economic, $\mathrm{S}=$ Socio-cultural, $\mathrm{T}=$ Technological

${ }^{5}$ Adopted from different related empirical and theoretical literature reviews and using data flow diagram tool (Hoffer, Jeffery; System Analysis and Design) 


\subsubsection{Micro Enterprises Development to Poverty Reduction Model(MEDPRM)}

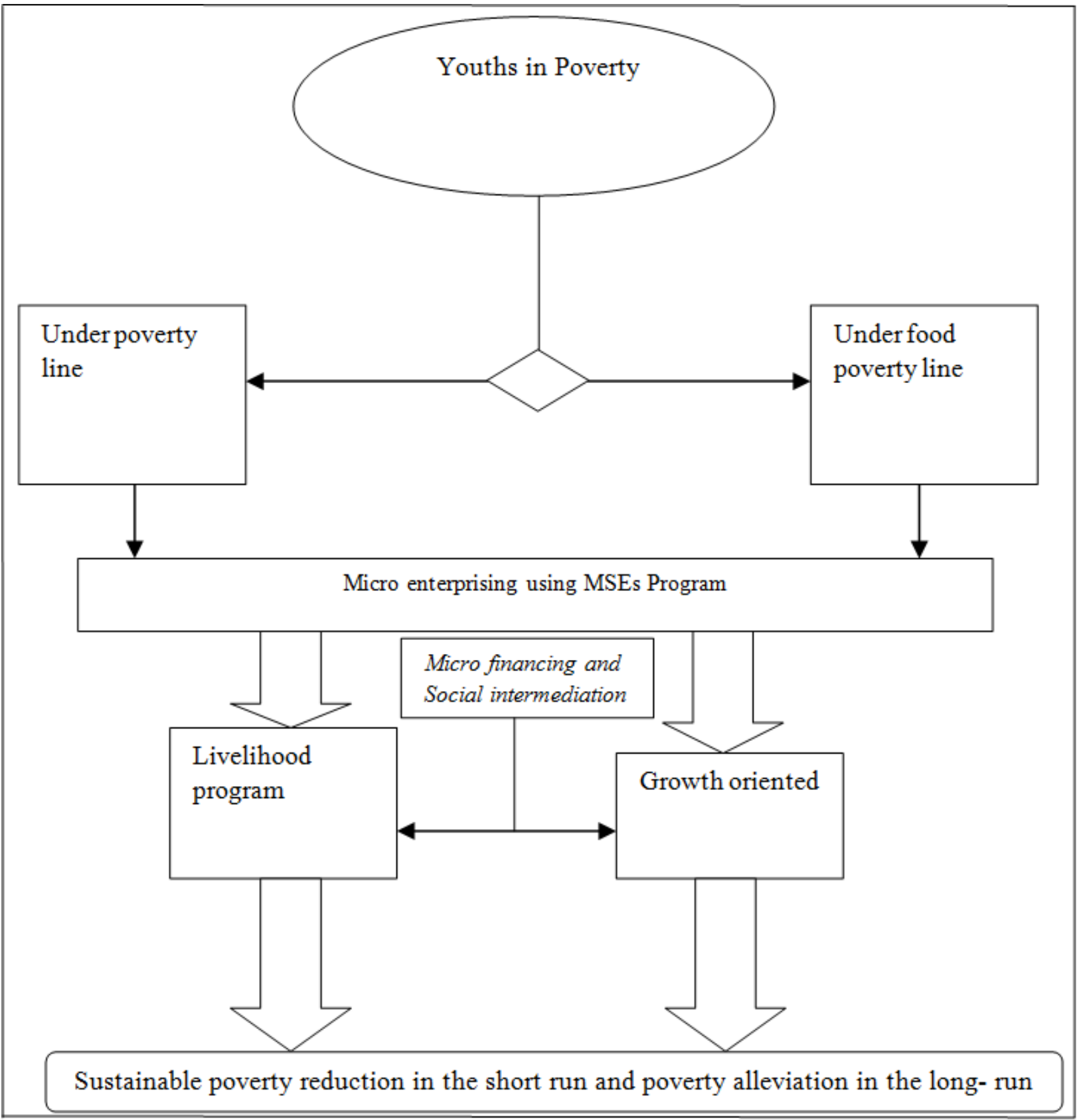

${ }^{6}$ Own model based on the available MSE programs and the financial capacity of youths (under poverty, under food poverty line)

Fig. 2. Micro Enterprises Development to Poverty Reduction Model (MEDPRM) ${ }^{6}$

\section{(i) Data Quality Control}

Pretest was conducted in $5 \%$ of the study population in Addis Ababa selected for study to assess the reliability of data collection instruments. The questionnaire was prepared in English and translated to Amharic for interview. The completeness of the questionnaire was checked during and after collection.

\section{(ii) Ethical Considerations}

Formal letter written from Unity University, Faculty of Business and Economics and permission from Addis Ababa Sub cities administrative office were obtained to conduct the study. The study participants were informed about the purpose of the study and informed verbal consent was obtained from each participants before data collection. Finally confidentiality was assured and the data was kept by avoiding personal identifiers. The result of the study was disseminated to Department of Economics, office of Unity University, Faculty of Business and Economics. In addition to this the finding of the study provided and disseminated to local Department of Economics, the nearby Business and Economics institutions to update information and make use of it for intervention. 


\section{Results}

\subsection{Characteristics of Youth Group Targeting Microenterprise Operators}

\subsubsection{Profile of Respondents in Terms of Age Distribution}

From the primary data gathered in the survey sample for analysis purpose $59.2 \%$ of them were male and $40.8 \%$ of them were female respondents. All of the above respondents were belongs to youth (15 - 29 years old) category. However, $7.5 \%$ of them were from $15-19$ years old, $28.3 \%$ of them were from 20-24 years old, and $64.2 \%$ of them were from 25 29 years old. Moreover, $40.85 \%$ of them were married, from which $57.1 \%$ of them were male and $42.9 \%$ of them were female, similarly, $1.67 \%$ of the respondents were divorced from which $100 \%$ of them were male. The remaining $57.5 \%$ of the respondents were not married out of these respondents the gender distributions accounts to $59.4 \%$ and $40.6 \%$ to male and female respectively.

In livelihood programs, microenterprises could play the flowing roles to development.

1. Since, microenterprises can be sources of selfemployment, and employment opportunities to the unemployed youths, youths in this programs can improve their unemployment problem

2. By having self- employment or employment opportunity to others, they could play in poverty reduction activities. Thus, they can play greater role to the achievements of the Ethiopian Transformation Plan (2010-2015) poverty alleviation objective.

3. Livelihood microenterprises are also sources of tax, thus they have also their own contribution to the expansion of infrastructures as well as the development of the nation.

4. Female microenterprises operators in livelihood programs can reduce their risk to child mortality rate in the case of unwanted pregnancy, since they can solve their financial problem through participating in such programs. Moreover, these operators can improve their educational status as to their capability to pay tuition fees. As the educational status of female micro enterprise operators/owners (i.e. youth) increases, the growth of their micro enterprises also increases. Thus, in the long- run, such microenterprises could be change in to growth-oriented microenterprises.

\subsubsection{Profile of Respondents in Terms of Previous Job Status}

From the total respondents $32.5 \%$ of them were unemployed, $1.7 \%$ of them were guards/servants, $5 \%$ of them were shopkeepers, and $0.8 \%$ of them were waiters, $29.2 \%$ of them were students, $25.8 \%$ of them were employed, and $5 \%$ of them were participating in other activities before they started in such micro enterprises activity (previous job status). Others includes youths were under employed and working in Arab counties.

\subsubsection{Profile of Respondents in Terms of Gender Distributions}

The gender distribution of male and female to the respondents' previous job statuses that were included in this sample study (i.e. unemployed, employed, shopkeepers, guards/servants, waiters, students and others), presented in table 1 below.

Table 1. Profile of youth respondents to their previous job status and gender distributions.

\begin{tabular}{lll}
\hline \multirow{2}{*}{ Previous job status of youths } & Gender & \\
\cline { 2 - 3 } & Male & female \\
\cline { 2 - 3 } & $\mathbf{\%}$ & $\mathbf{\%}$ \\
\hline Unemployed & 26.76056 & 40.81633 \\
Underemployed & 30.98592 & 18.36735 \\
Student & 30.98592 & 26.53061 \\
House made/guardian & & 4.081633 \\
Shop keeper & 4.225352 & 6.122449 \\
Waiter & & 2.040816 \\
Others & 7.042254 & 2.040816 \\
Total & 100 & 100 \\
\hline
\end{tabular}

\subsection{Characteristics of Microenterprises}

\subsubsection{Forms of Ownership of Youth Group Microenterprises}

According to this study sample survey, $38.3 \%$ of them formed in sole proprietorship, $12.5 \%$ of them formed in partnership, and $49.2 \%$ of them formed in corporation form of micro enterprises. See figure 3 below:

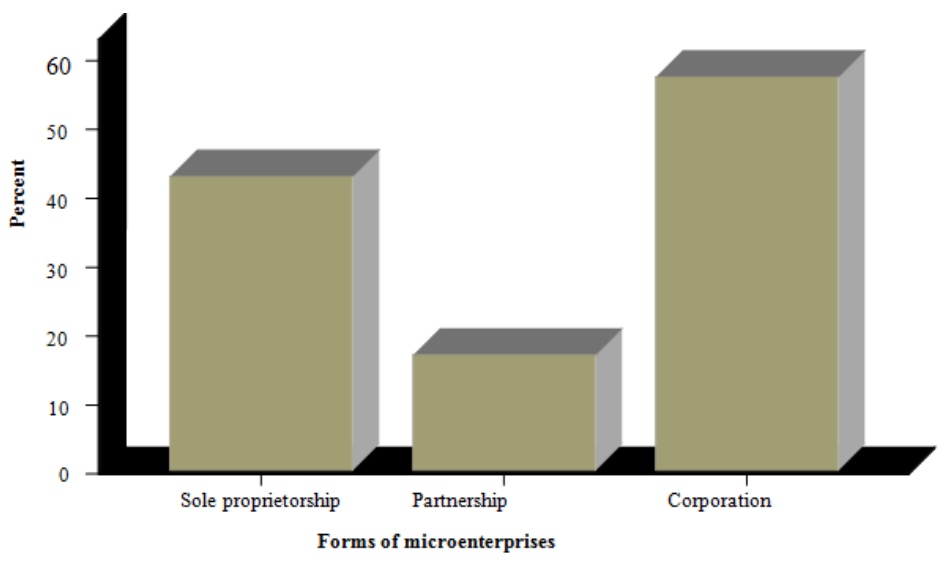

Fig. 3. Forms of Youth targeting Microenterprises. 


\subsubsection{Sources of Initial Capital}

In terms of sources of initial capital, the result of the survey study shows that, $0.8 \%$ of respondents get their initial capital from governmental organizations. Similarly, $15 \%$ of them were from saving, $4.2 \%$ of them were from non governmental organizations, $34.2 \%$ of them were from family, $37.5 \%$ of them were from micro finance organizations, $1.8 \%$ of them were from relatives, and the remaining $6.7 \%$ of them were obtained their initial capital from other sources. Others sources includes: both family and microfinance, saving and microfinance, friends and family, family and savings from working in Arab countries.

\subsubsection{Motivational Factors to Start Microenterprises}

Youths motivated by different factors to participate in different activities. Similarly, in this survey study findings, youths motivated by different motivational factors. These factors were government policy, entrepreneurship, income level, and economic independency, absence of any other choice, self-employment, peer influence (friends), media, job status, motivation, educational background, family background, market gap and attitudinal factors.

From the total number of respondents, $20 \%$ of them motivated by government policy, $33 \%$ of them motivated by income level, and $6.7 \%$ of them motivated by independency. Similarly, $0.8 \%$ of the respondents motivated by absence of any other choice, $27.5 \%$ of them motivated by self employment, $27.5 \%$ of them were motivated by peer influence (friends), $1.7 \%$ them were motivated by media. Moreover, $4.2 \%, 5.8 \%, 5 \%, 5.8 \%, 2.5 \%$ and $5 \%$ of the respondents were motivated by job status, motivation educational back ground ,family back ground, market gap, and, entry in to entrepreneurship respectively. Other motivational factors accounts to $8.3 \%$. These are absence of any other choice and government policy; income level and government policy; entry in to entrepreneurship and educational background; family background and income level; self-employment, entry in to entrepreneurship and income level; family background, government policy, and educational back ground; income level, family background, educational status, and government policy. The above results also presented in table 2 as below:

Table 2. Youth's motivational factors to start microenterprise activities.

\begin{tabular}{llllll}
\hline Serial no. & Motivational factors & Frequency & Percent & Valid Percent & Cumulative Percent \\
\hline 1 & Government policy & 24 & 20 & 20 & 20 \\
2 & Independency & 8 & 6.7 & 6.7 & 26.7 \\
3 & Ambition or motivation & 7 & 5.8 & 5.8 & 32.5 \\
4 & No other choice & 1 & 0.8 & 0.8 & 33.3 \\
5 & Entry in to entrepreneurship & 6 & 5 & 5 & 38.3 \\
6 & Others & 12 & 10 & 10 & 50.3 \\
7 & Pear influence & 2 & 1.7 & 1.7 & 55 \\
8 & Level of education & 6 & 5 & 5 & 82.5 \\
9 & Self-employment & 33 & 27.5 & 27.5 & 84.2 \\
10 & Media & 2 & 1.7 & 1.7 & 90 \\
11 & Family background & 7 & 5.8 & 5.8 & 93.3 \\
12 & Level of income & 4 & 3.3 & 3.3 & 97.5 \\
13 & Occupational background & 5 & 4.2 & 4.2 & 100 \\
14 & Gap in the market & 3 & 2.5 & 2.5 & 100 \\
\hline
\end{tabular}

\subsubsection{Objectives of Micro Enterprises}

Micro enterprises, which were included in this study, sample survey in terms of having vision shows that $10.8 \%$,
$9.2 \%$ and $80 \%$ of them accounts to viable, survival and profit earning respectively. This result distribution was different in different sub cities and presented in figure 4 as follows:

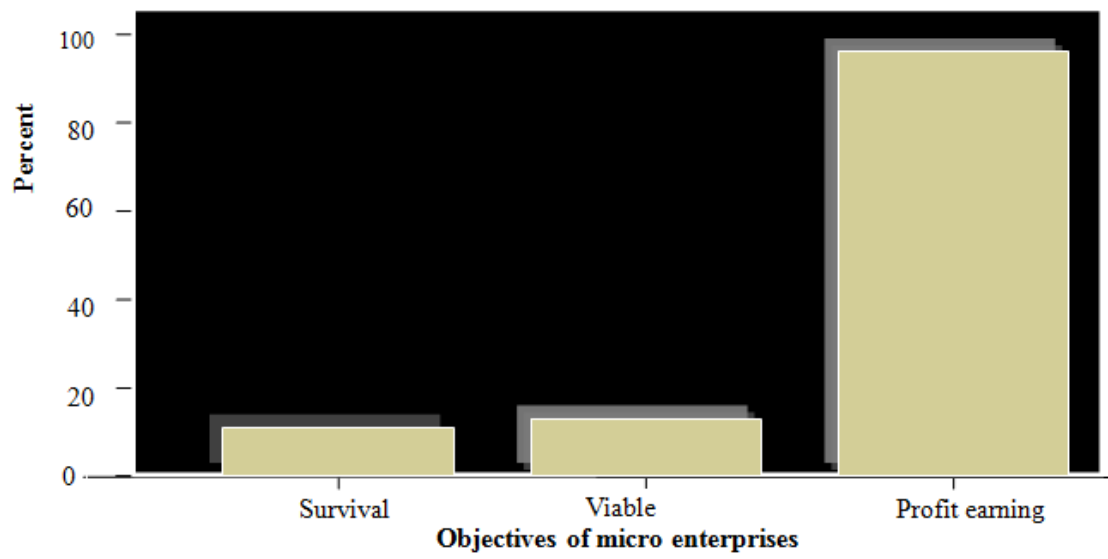

Fig. 4. Objectives of Youth targeting microenterprises. 


\subsubsection{Youths and Employment in Micro Enterprises}

Micro enterprises in Addis Ababa have different characteristics, micro enterprises in which only youth groups are operating the form of ownership are with limited employees. Most of the time, youths are working with other age categories (i.e. beyond the ages of this study scope which is greater than 29 years old. Hence, the essence of this study is to assess and analyze the status, shortcomings and prospects of micro enterprises operated (owners/ employees) of youths. The questionnaires of this study were prepared by accompanying guidelines, which restricted to be filling by youth groups. The results of this study in regarding to employment described as follows: - According to the results of this study survey, 1052 numbers of employees were working in different micro enterprises activities in Addis Ababa these activities were woodwork and metalwork, IT, construction, food preparation, urban agriculture, cobble stone projects, bookstores, municipal activities, and textile activities. These activities identified based on Addis Ababa MSE agency program. From the total number of employees $73.48 \%$ of them were male with a mean of 6.4 and $26.52 \%$ of them were females with a mean of $2.325 \%$. From the total number of employees, $87.64 \%$ of them were youth employees. From the total number of youth employees $77.77 \%$ of them were permanent employees and $22.23 \%$ of them were part timers.

Table 3. Profile of youth targeting microenterprises having only permanent/both permanent and part timer employees.

\begin{tabular}{lllll}
\hline $\begin{array}{l}\text { Only } \\
\text { permanent }\end{array}$ & Frequency & Percent & Valid Percent & $\begin{array}{l}\text { Cumulative } \\
\text { Percent }\end{array}$ \\
\hline yes & 80 & 66.7 & 66.7 & 66.7 \\
no & 40 & 33.3 & 33.3 & 100 \\
Total & 120 & 100 & 100 & \\
\hline
\end{tabular}

According to the results of this study sample survey, from the total number of respondents who responded as "youth target microenterprises were not obtained any support from the different supports provided by governmental and nongovernmental organizations", $60.78 \%$ of them leveled its essentiality as very important. Similarly, $15.67 \%$ of them leveled as important, $13.73 \%$ of them as moderate, no one of them as low and as not- important to its essentiality for their microenterprises. The remaining $9.8 \%$ of the respondents accounts to others. Others include non-respondents, and selfsufficient (no need of supports). This result also presented in table 4 as follows:

Table 4. Responses to the essentiality of organizational supports to youth target microenterprises.

\begin{tabular}{llllll}
\hline Serial no. & Levels & Frequency & Percent & Valid Percent & Cumulative Percent \\
\hline 1 & Very-important & 31 & 60.8 & 60.8 & 15.7 \\
2 & Important & 8 & 15.7 & 13.8 & 0 \\
3 & Moderate & 7 & 0.8 & 0 & 0.2 \\
4 & Low & 0 & 0 & 0.2 & 9.8 \\
5 & Not important & 0 & 9.8 & 10.2 & 100 \\
\hline
\end{tabular}

\subsubsection{Microenterprises Location Setting}

According to the results of study sample survey, from the total number of respondents $26.7 \%$ of them responded as absence of other alternatives other than the current location, $43.3 \%$ of them responded as an authorized body provided the current location, and $25.8 \%$ of them responded as profitability of the current location were the basis of youths targeting microenterprises location setting. The remaining $4.2 \%$ of them accounts to others. Others include nonrespondents. This result presented in table 5 as follows:

Table 5. Microenterprises location setting by youth groups in Addis Ababa (2010).

\begin{tabular}{|c|c|c|c|c|c|}
\hline Serial no. & Reasons of respondents & Frequency & Percent & Valid Percent & Cumulative Percent \\
\hline 1 & Others & 5 & 4.2 & 4.2 & 4.2 \\
\hline 2 & Because you have only this chance & 32 & 26.7 & 26.7 & 30.8 \\
\hline 3 & Because the authorized body provide it to your enterprise & 52 & 43.3 & 43.3 & 74.2 \\
\hline \multirow[t]{2}{*}{4} & Because you thought it is more profitable business location & 31 & 25.8 & 25.8 & 100 \\
\hline & Total & 120 & 100 & 100 & \\
\hline
\end{tabular}

\subsubsection{The Use of Consultancy Service by Microenterprises Targeting Youth Group}

The results of this study sample survey shows that from the total number of respondents $28.3 \%$ of them responded that microenterprises were using consultancy services where as $68.3 \%$ of them were not using consultancy services. From the total number of microenterprises which were using consultancy services $5 \%$ of them evaluated its essentially for the growth and expansion of their 
microenterprises as low, $8 \%$ of them as moderate, $33 \%$ them as good, and $54 \%$ of them as very good. Their evaluations were based on the changes obtained by their enterprises growth and expansion in use of consultancy services. From the consultancy service organizations which providing services for the growth and development of youth targeting microenterprise organizations DOT and NET consultancy services was available. Moreover, AdCSI (Addis Credit and Saving Institute) also provide consultancy services and trainings for such enterprises.

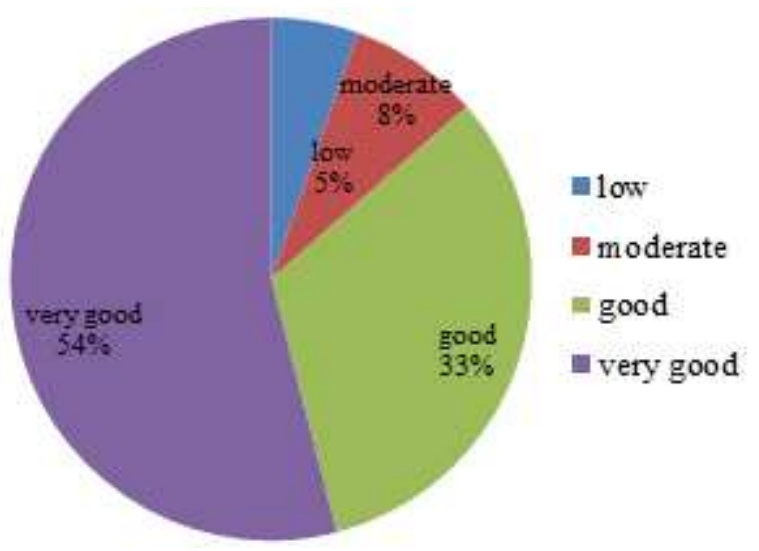

Fig. 5. Respondents evaluation from the use of consultancy services.

\section{Discussions and Conclusion}

\subsection{Discussions}

The current overall development objective of Ethiopia is achieving end poverty through accelerated and sustained economic growth by giving greater emphasis to the improvement of employment opportunities for youth and women. With unemployment, ranging from 25 to 45 percent in most developing countries, "self-employment" and micro enterprise development seen by many donor agencies as the only way to reach the "poorest of the poor". The donors feel that without strong private enterprises, third world countries cannot hope to enter international trading systems. The unemployment rate of youth group is currently $31.46 \%$ in Addis Ababa. In Ethiopia, the on-going micro and small enterprises (MSEs) development complemented by the formulation and implementation of women and youth packages is to address unemployment and under employment problems. Given these ongoing efforts, the challenges may not, to be insurmountable. In this respect, the policy formulation process requires an assessment of the currentstatus, shortcomings and prospects of micro enterprises. The intended purpose of this study is to assess, and analyze micro enterprises targeting youth group to socio economic development in terms of poverty reduction, women empowerment, employment, entrepreneurship, and asses the status, challenges and its prospects in the case of Addis Ababa. According to the results of this survey study, majority of micro enterprises are corporation form of ownership, which accounts to $49.2 \%$ from the total number of microenterprises operated by youth groups. In terms of sources of initial capital, majority of youth targeting micro enterprises obtained from microfinance institutions, which accounts to $37.5 \%$ out of the total microenterprises included in the sample survey study. Moreover, majority of microenterprises were formed between years 2005 to 2008G.C. Majority of youths were motivated by selfemployment and government policy to start such business activities which accounts to $27.5 \%$, and $20 \%$ respectively. In terms of setting vision to their enterprises majority of youth group microenterprises were set their own vision to their enterprises. Even if majority of youth group microenterprises were set their vision to their enterprises, majority of these enterprises were set their vision during operation rather than before and at start up. Concerning the objectives of microenterprises to their establishment, the result of this survey study shows that majority of youth group microenterprises were belongs to profit earning microenterprises. However, from those microenterprises, which belong to survival microenterprises, majority of them have a strategic plan of diversification for the growth and development of their (young entrepreneurs) enterprises. According to the results of this study survey, 1052 numbers of employees were working in different micro enterprises activities in Addis Ababa. From the total number of employees majority of them were male and $87.64 \%$ of them were belongs to youth groups. Moreover, from the total number of youth employees, majority of them were permanent employees, which accounts to $77.77 \%$. However, out of the total number of part time youth employees working in micro enterprises, majority of them were family members, which accounts to $58.54 \%$. In terms of having permanent and part time employee distributions, the results of the survey study shows that majority of youth group microenterprises $(66.7 \%)$ have only permanent employees. Additionally, most of the respondents believed that employment in microenterprises could reduce poverty, furthermore, majority of these respondents leveled as high in terms of its extent to poverty reduction. In terms of the different supports provided by governmental and nongovernmental organizations to youth targeting micro enterprise operators in Addis Ababa, the results of this survey study shows that, majority of youth targeting microenterprises benefited from the different supports which obtained from governmental and nongovernmental organizations. Out of these, majority of youth group microenterprises were get different supports from governmental organizations. However, from the total number of respondents who responded as "youth target microenterprises were not obtained any support from the different supports provided by governmental and nongovernmental organizations"; majority of them leveled its essentiality as very important for the growth of their enterprises. Furthermore, majority of youth target microenterprises had provided financial and non-financial supports from Addis Ababa MSE Agency. According to the results of this study sample survey findings, the following three constraints are the most serious problems that youth 
targeting micro enterprises are facing currently in Addis Ababa. These are: Place (inadequate working area, storage, and sales), and Location; Shortage of financial resources and constraints of credit access; Misunderstanding, disagreement, and mistrust among group members.

From the available psychosocial constraints that microenterprise operators facing, afraid of failure and criticism, faulty socialization, low dignity of labor, and in adequate motivation are the most serious problems. Even if supports i.e. financial and non - financial supports has provided to those micro enterprises, they are also demanding different supports from Addis Ababa MSE Agency in the future. To this respect, majority of the respondents are demanding growth oriented supports that could enable them to grow their enterprises in to small and medium enterprises. The results of this survey findings shows that from the different supports provided by youth targeting microenterprises, psychological and finical supports are the major supports to female operators. Moreover, majority of microenterprises operating by youths were undertaking quality control and quality standards. However, from the total number of microenterprises which undertaking quality control and quality standard activities, most of these microenterprises are undertaking controls over production. On the other hand, microenterprises, which are not undertaking quality control and quality standards, were due to different reasons, these are absence of testing facilities, attitude of microenterprises operators as it is not necessary for their enterprise, lack of technical skills to undertake, and high cost from higher to lower reasons hierarchically.

The basis of young entrepreneurs location setting for their microenterprises is due to different factors, however, the results of this study shows that majority of them were set their location because an authorized body provided the current location to their microenterprises. According to this survey study findings majority of youth group microenterprises are not using consultancy services, which accounts to $68.3 \%$, and their major reason were lack of awareness.

\subsection{Conclusion}

According to the results of this survey findings, majority of microenterprises are not using consultancy services. On the other hand, microenterprises that were using consultancy services identified as very important for the growth and expansion of their enterprises. Despite, the result shows that lack of awareness is the main reason for not using consultancy services. Thus, there should be creating awareness creation, and providing favorable policy framework to the sector. Moreover, low cost and availability of the service in a nearby to this enterprises facilitates the growth of such enterprises. In addition, the expansion of such activities creates job opportunities for others i.e. selfemployment and employment opportunities. Thus, policy makers, MSE Agency, media, and stakeholders of the sector should design favorable conditions for its success. Hence, consultancy services are aimed to provide valuable information to microenterprises such as efficiency, quality, standardizations, marketing strategies (for example, diversification, market development, product development, marketing mix, and different strategies in product life cycle, market expansion, customer handling and customer satisfaction, quality service provision). In addition, they can provide feedbacks and essential information to system development such as managerial and financial in which such enterprises to become successful (profitable) as well to come up from failures. However, the results of this survey study shows that majority of young entrepreneurs obtain their initial capital from microfinance institutions. Consequently, taking in to considerations of their living cost, interest rate, and low level of profit at start up, challenges of market competition, other dependent family members, retained earnings, school fees, and operation costs, payments to consultancy services may not be affordable and challenging to such young entrepreneurs specially for the poor youths. As a result, policy makers has to implement a strategy for providing zero or less cost consultancy services to such enterprises at least at startup specially for poor youths. Moreover, NGOs could also play a great role for its success.

Constraints of the sector such as place (inadequate working area, storage, and sales), and location; shortage of financial resources and constraints of credit access; misunderstanding, disagreement, and mistrust among group members, which were identified in this study as the three most serious problems specifically, for youth target microenterprises, which have to be solved. Hence, microenterprises sources of income generation, employment and entrepreneurial cultural development, they have to be strengthening through solving their constraints and providing different supports that could increase their productivity, increasing returns to scale and profitability. This results microenterprises to grow in to small and medium enterprises as mentioned in the model. This in turn results to absorb unemployment problem, high contribution for GDP, import substitution and enables youths to have freedom of choice, purchasing power, reinvestment and "capabilities". To this end, youth target microenterprises could be the main pillar strategies for the country's socio economic development strategy behind serving as equal and equity distribution of income.

This can be achievable through the coordination of the different stakeholders of the sector such as: the Addis Ababa City Municipality, Addis Ababa MSE Agency, Addis Ababa Youth Association, Microfinance Institutions, and NGOs. Since, place costs such as working area, storage, and sales results to higher costs and it in turn affects their profit .On the other hand, providing such access to young entrepreneurs enables to be profitable(comparative advantage).Thus, stakeholders has to work for solving such problems. Moreover, through providing high emphasis for the sector such as investment for research and development (R\&D), favorable monetary and fiscal policy and technological transfer the success of the model as well as GTP objective is surmountable. Hence most of the activities operated by such 
enterprises are endogenous products, high emphasis have to be given for their growth, expansion and development. Protection mechanisms to protect this infant organization have to be implemented and strengthened. Though, it can resolve problems against market demand and competition in the market; despite, they are not using high technology. Additionally, location also affects the profitability of such enterprises, thus right location has to be provide to such enterprises. Since, the results of this survey study shows that majority of young entrepreneurs were set their location because an authorized body provided the current location to their microenterprises, right locations (i.e. sales area and shorter distance working area) has to be provided whenever such supports are provide to microenterprises. Additionally, in order to identify right location by such enterprises marketing research has to be made, however, undertaking marketing research by such enterprises will be expensive as a result, Addis Ababa MSE Agency and other stakeholders has to support such enterprises at start up by providing place supports with right location i.e. through marketing research.

\section{Author's Contributions}

MKA, have made substantial contributions to beginning and design, collection of data, analysis and interpretation of data and in drafting the manuscripts and correcting the comment given by the advisors.

DM involved in revising the research paper and the manuscript critically for important intellectual context, approval of the final version to be published. Also, he participated in its design and coordination. He participated in the approval and funding process, participated in the design of the study participated in its design and coordination.

AAG had greater contribution in reviewing the manuscript English, topography and helped to draft the manuscript.

YYA had greater contribution in reviewing the manuscript English, topography, and helped to draft the manuscript.

\section{Acknowledgements}

We are thankful to all our department technical staffs for their excellent technical support. We are grateful to all the participants for their cooperation and all my best friends and my families for financial support during this successful research.

\section{Funding/Support}

This study was supported by only my best friends and families during study. Otherwise I didn't get any fund for this paper.

\section{References}

[1] AAYA (Addis Ababa Youth Association) (2011G.C).Addis Ababa Youth Association Semi Annual Report of the Plan Year 2003 E.C (Amharic). (n.p). Addis Ababa, Ethiopia.
[2] ADB (Asian Development Bank) (1997 G.C). Micro Enterprise Development: Not By Credit Alone. Asian Development Bank. (n.p).

[3] AdCSI (Addis Credit and Saving Institution /s.c/) (2008 G.C)Addis Credit and Saving Institution/ s. c / Policy.(n.p): Addis Ababa, Ethiopia.

[4] Altekar, Rahul V. (2007 G.C) Enterprise Wide Resource Planning: Theory and Practice. 4th Printed. Prentice Hall of India Private Limited. New Delhi, India.

[5] AndualemTegegne (2005 G.C). Small Scale Enterprises and Entrepreneurship Development in Ethiopia: Concepts Definitions and Major Issues. In Wolday Amha et.al. (Eds.) (1997 E.C.).Small Scale Enterprise Development in Ethiopia, Proceedings of the Sixth Annual Conference on the Ethiopian Economy, Addis Ababa.

[6] Murathi,A., Weda,JO(2015). Critical Factors in Repayment of Constituency Youth Enterprise Scheme in Kirinyaga Central District, Kenya. Journal of Finance and Accounting.3(2):1927. doi: 10.11648/j.jfa.20150302.11, Science publishing group, USA.

[7] CSA (Central Statistical Agency) (2010 G.C). Analyzed Report on : the 1999 National Labor Force Survey (1999 E.C.) Statistical Bulletin 234. Printed in CSA. Addis Ababa, Ethiopia.

[8] CSA (Central Statistical Agency) (2010 G.C).Statistical Report on: The 2010 Urban Employment Unemployment Survey: Printed in CSA. Addis Ababa, Ethiopia.

[9] CSA (Central Statistical Agency) (2010 G.C).Statistical Report on: The 2010 Urban Employment Unemployment Survey: Addis Ababa City Administration. Printed in CSA. Addis Ababa, Ethiopia.

[10] Desai, Vasant (2001). Dynamics of Entrepreneurial Development and Management. Millennium eds. Himalaya Publishing House. Mumbai, India.

[11] Gebrehiwot Ageba and Wolday Amha. (2001 G.C). Micro and Small Enterprises Development in Ethiopia: Strategy, Regulatory Changes and Remaining Constraints. "Ethiopian Journal of Economics" (EEA) .Volume X, Number 2.Published 2006. Addis Ababa, Ethiopia.

[12] Getachew Abebe and Getachew Belay (2005 G.C). Micro Business Development in Ethiopia. In Wolday Amha et al (Eds) (1997 E.C.). Small-Scale Enterprise Development in Ethiopia, Proceedings of the Sixth Annual Conference on The Ethiopian Economy. Ethiopian Economic Association (EEA); Addis Ababa University, Department of Economics. Addis Ababa.

[13] "Government Compliance on Micro and Small Enterprises" Addis Admas (Amharic), 27 Feb. (2003 E.C.)

[14] Growing Micro and Small Enterprises in LDCs, The "Missing Middle" in LDCs: Why Micro and Small Enterprises are not Growing.

[15] Gujarati, Damodar N. (2004 G.C).Basic Econometrics. 4th ed. The McGraw-Hill Companies, Inc. New York, USA.

[16] Hailay Gebretinsae Beyene (PhD) (2007 G.C). Entrpreneurship and Small Business Management. 2nd ed. Mekelle University, Faculty of Business and Economics. Mekelle, Ethiopia. 
[17] Hayat Abdulahi (n.d). Constraints to Women Entrepreneurs in the Informal Sector: The case of Women Traders in Addis Abba Markets. In Wolday Amha et al (Eds.) (1997 E.C.).Small Scale Enterprise Development in Ethiopia, Proceedings of the Sixth Annual Conference on the Ethiopian Economy. Ethiopian Economic Association (EEA); Addis Ababa University, Department of Economics. Addis Ababa.

[18] Levitsky, Jaccob (1989 G.C). Micro Enterprises in Developing Countries (in book of Jaccob Levetisky): Paper Presented in the Inter-Nations Conference held in Washington D.C, U.S.A.

[19] Man Sour (1999 G.C). The Urban Informal Sector in Developing Countries: Employment, Poverty and Environment. ILO. Geneva, Switzerland.

[20] Prezioso,M.,Coronato,M(2014). Entrepreneurship and Territorial Behavior. How to Exercise Competitiveness in Sustainability in Europe. Social Sciences. Special Issue: Geographical evidence in changing Europe. 3(4-1): 28-45.doi: 10.11648/j.ss.s.2014030401.14, Science publishing group, USA.

[21] MOE (Ministry of Education) (2009 G.C). Middle Level Technical and Vocational Training Program: Stimulating Entrepreneurship and Small Business Creation (Principles and Practice). 2nd ed. Mega Printing Enterprise. Addis Ababa, Ethiopia.

[22] MOFED (Ministry of Finance and Economic Development) (2010 G.C). The First Five Years (1998 to 2002 E.C.) Development Plan Implementation and The next five years (2003 to 2007 E.C.) Growth and Transformation Plan Preparation: Inception Report for Panel Discussion to: The Federal Government Conference. (n.p). Addis Ababa, Ethiopia.

[23] MOFED (Ministry of Finance and Economic Development) (2010 G.C). Ethiopia: Country Report on the Implementation of Brussels Program of Action (BPOA).Addis Ababa, Ethiopia.

[24] MOFED (Ministry of Finance and Economic Development). (2010 G.C). Federal Democratic Republic of Ethiopia, Growth and Transformation Plan 2010/11-2014/15.Volume II, Policy Matrix. Artistic Printing Enterprise. Addis Ababa, Ethiopia.
[25] MOFED (Ministry of Finance and Economic Development). (2010 G.C). Federal Democratic Republic of Ethiopia, Growth and Transformation Plan 2010/11-2014/15.Volume I, Main Text. Artistic Printing Enterprise. Addis Ababa, Ethiopia.

[26] MOIT (Ministry of Industry and Trade) (2005 G.C). Micro and Small Enterprises Development Strategy. Federal Democratic Republic of Ethiopia, Ministry of Trade and Industry, Addis Ababa.

[27] MSE (Micro and Small Enterprise) (2006 G.C). Urban Industry and Urban Development Package: Micro and Small Enterprises Development Program Urban Agricultural Sector Support Package (Amharic). Birhanena Selam Printing Enterprise. Addis Ababa, Ethiopia.

[28] MSE (Micro and Small Enterprise) (2006). Urban Industry and Urban Development Package: Micro and Small Enterprises Development Program Food processing Sector Support Package (Amharic). Birhanena Selam Printing Enterprise. Addis Ababa, Ethiopia.

[29] MSE (Micro and Small Enterprise) (2011). Addis Ababa City Administration, Micro and Small Enterprises Agency: Inception Report on Micro and Small Enterprises Development in Addis Ababa. (n.p). Addis Ababa, Ethiopia.

[30] Raj, Felix (et.al.) (2006 G.C). Contemporary Development Economics: From Adam Smith to Amartya Sen. New Central Book Agency Pvt. Ltd. Chintamoni Das Lane, India.

[31] Romer, David (1996 G.C). Advanced Macro Economics. McGraw- Hill Companies, Inc. USA.

[32] Das,SK.,Bhowal, A(2013). Impact of Micro Finance: Perceptions of Direct Stakeholders of Self Help Groups, International Journal of Business and Economics Research. 2(6):142-157. doi: 10.11648/j.jiber.20130206.14, Science publishing group, USA.

[33] Wallace, John. (n.d). Small Scale Enterprise Development in Africa: Lessons from Success. Marshal University.

[34] WB (World Bank) (1989 G.C). Sub Saharan Africa from Crisis to Sustainable Growth. The World Bank. Washington D.C, USA. 